\title{
ETHICAL ASPECTS IN THE MANAGEMENT OF THE TERMINALLY ILL PATIENT IN THE PEDIATRIC INTENSIVE CARE UNIT
}

\author{
Lara de Araújo Torreão, Crésio Romeu Pereira and Eduardo Troster
}

TORREÃO L de A et al. - Ethical aspects in the management of the terminally ill patient in the pediatric intensive care unit.

Rev. Hosp. Clín. Fac. Med. S. Paulo 59(1):3-9, 2004.

OBJECTIVE: To identify the prevalence of management plans and decision-making processes for terminal care patients in pediatric intensive care units.

METHODOLOGY: Evidence-based medicine was done by a systematic review using an electronic data base (LILACS, 1982 through 2000) and (MEDLINE, 1966 through 2000). The key words used are listed and age limits (0 to 18 years) were used.

RESULTS: One hundred and eighty two articles were found and after selection according to the exclusion/inclusion criteria and objectives 17 relevant papers were identified. The most common decisions found were do-not-resuscitation orders and withdrawal or withholding life support care. The justifications for these were "imminent death" and "unsatisfatory quality of life".

CONCLUSION: Care management was based on ethical principles aiming at improving benefits, avoiding harm, and when possible, respecting the autonomy of the terminally ill patient.

DESCRIPTORS: Terminal care. Ethics. Life support care, pediartics. Pediatric intensive care unit.

Technological and scientific developments in the past few decades have nourished the growth of critical care medicine. Improvements in support therapy have been countless in the management of organic failure and include mechanical ventilation, renal replacement therapy, vasoactive drugs, parenteral nutrition, and others. Therefore, the complexity of the treatments has expanded, and other possibilities are avalible in cardiac surgery, neurosurgery, and organ transplantation.

Consequently, with the effectiveness of the new diagnostic and therapeutic approaches, there has been an increase in life expectancy, and the mortality index has decreased. Therefore, we have more chronic and termi- nally ill patients as well. Children who in the past would have died, nowdays survive, sometimes with no significant morbidity but sometimes with severe permanent sequelae. In the latter cases, without the "benefits" of the intensive care treatment, the child would have succumbed by the natural evolution of the disease. That is, as medical technology has enhanced our ability to sustain life in the PICU, ethical ques-

From the São Rafael Hospital and Pediatric Wards of the Hospital das Clínicas, Federal University of Bahia - Salvador/BA, Brazil; Department of Clinical Epidemiology, Childrens's Institute, Hospital das Clínicas, Faculty of Medicine, University of São Paulo - São Paulo/SP, Brazil.

Received fo publication on April 08, 2003. tions have become more pressing. Can we, or should we, treat every child utilizing every therapeutic tool available? And, if we should, which limits shall we respect? These questions could reflect a degree of therapeutic obstinateness when resources are used in an exaggerated and futile manner that goes against ethical and moral principles $^{1,2}$.

Bioethics arises in this context when there is an exponential growth in scientific knowledge, and the use of it in the medical field results in conflicts with the therapeutic limits. This conflict contributes to ethical questioning in the decision-making about end-of-life care. Terminally ill patients are defined as patients who are in the 
stage of the disease that will undoubtedly progress to death, independently of all efforts; patients who are undergoing end-of-life care cannot be "saved" 3-5.

Bioethics has established 4 basic principles: beneficence, non-malfeasance, autonomy, and justice ${ }^{6,7}$.

The principle of beneficence is the moral obligation to act to help others further their important and legitimate interests. In the terminally ill patient, the main goal is to promote the "benefits" and prevent and remove the "damage" The principle of non-maleficience derives from the Hippocratic saying: "Primum non nocere" (first, do no harm) that is, "one ought not inflict evil or harm directly". In the terminal stage of the disease, this principle is the basis for treatment and has as a main objective the avoidance of "disthanasia", or the process of slow death with suffering, usually prolonged by artificial methods ${ }^{7}$.

Disthanasia is the product of the therapeutic obstinateness following the irrational use of technology in the treatment of the patient when the condition is irreversible. This approach in the United States of America is named "futility therapy", since healing is impossible and the harm is greater than the benefit ${ }^{1,2,7-9}$

The principle of autonomy includes liberty rights, individual choice, and self-governance. This principle underlies the concept of informed consent, which consists of a process wherein the person receives a detailed explanation about the procedure, understands this information, acts voluntarily, and finally decides whether he/she consents or not. It is a conscientious act that can be renewed or withdrawn ${ }^{8,10}$.

Parents or tutors have the legal and ethical responsibility over the minor patient. They make their decisions based on their values and beliefs, which probably are the same as the ones of the child or adolescent when they live in and share the same sociocultural environment ${ }^{11}$.

The principle of justice refers to distributive justice, "giving to each his due". It is the principle that forces the guarantee of fair, equitable, and universal distribution of the benefits of health care in society ${ }^{712}$. Therefore, the use of excessive technological apparatus at the end of life is considered a bad allocation of resources and consequently unethical ${ }^{3,7}$.

Parallel to the technical and scientific advances in the critical care units, ethical questions and thoughts about the real benefit from the use and limiting of these technologies arise.

This study has as an objective to: 1) identify publications about the prevalence of the strategies adopted for the terminally ill patient in the pediatric intensive care units (PICUs); 2) analyze the decision-making processes in the management of the terminally ill patient adopted in the PICUs, reporting on the justifications for the discussed procedure, the people involved in making the decision, the initiation of the process, and the documentation in the chart.

\section{METHODS}

This is a systematic review of the literature with a critical analysis of the scientific articles, according to the technical criteria of recommendations based in evidence as suggested by Cook and Sacket ${ }^{13}$.

An electronic computerized search was performed in 2 databases: MEDLINE (1996 through 2000) and LILACS (1982 through 2000), with the objective to reach Northern-American, European, and Latin-American publications. The following key words were used in LILACS: "paciente terminal" and "ética médica". The key words used in MEDLINE were: "terminal care", "ethics", "life support", limited to the pediatric age group. This search was enriched by a manual search of the references of the studies, books, and editorials from relevant medical journals.

\section{RESULTS}

A total of 182 articles were found; with selection based on the inclusion and exclusion criteria, 83 studies were identified.

We were able to locate 58 of these studies $(70 \%)$, and another 8 articles were found with the manual searching, resulting in a total of 66 articles. After selection according to the objectives, 17 studies were selected (Fig. 1).1. Strategies adopted for the terminally ill patient in the pediatric intensive care unit Nine (9) studies describing the manner of dying in the PICU that supported decisions to forgo life-sustaining treatment, such as withhold (WH), withdraw (WD), or do-not-resuscitate (DNR) orders were identified, with 4 of them being cohort studies and 5 being retrospective studies ${ }^{14-22}$. Some articles referred to brain death (BD) as a type of death, but obviously, a patient with $\mathrm{BD}$ is not classified as a terminally ill patient. All the studies were performed in PICUs, with the exception of a Dutch study, in which $71 \%$ of deaths occurred in the PICU ${ }^{21}$.

The DNR order was studied, sometimes as a main event and sometimes as a omission of life support. In both situations, the strategy was maintaining every therapeutic support, and in the moment of death, resuscitative measurements were not performed. The other studies evaluated restrictive strategies (Table 1).

2. The decision-making process in the management of terminally ill patients adopted in the PICUs reporting on the justifications for the discussed procedure, the people involved in taking the decision, the initiation of the process, and the registration in the chart. 


\section{Exclusion of articles}

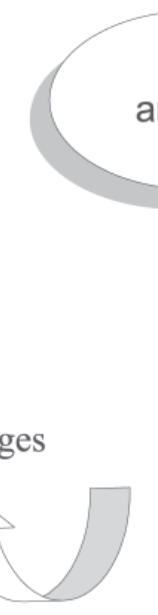

24 other languages
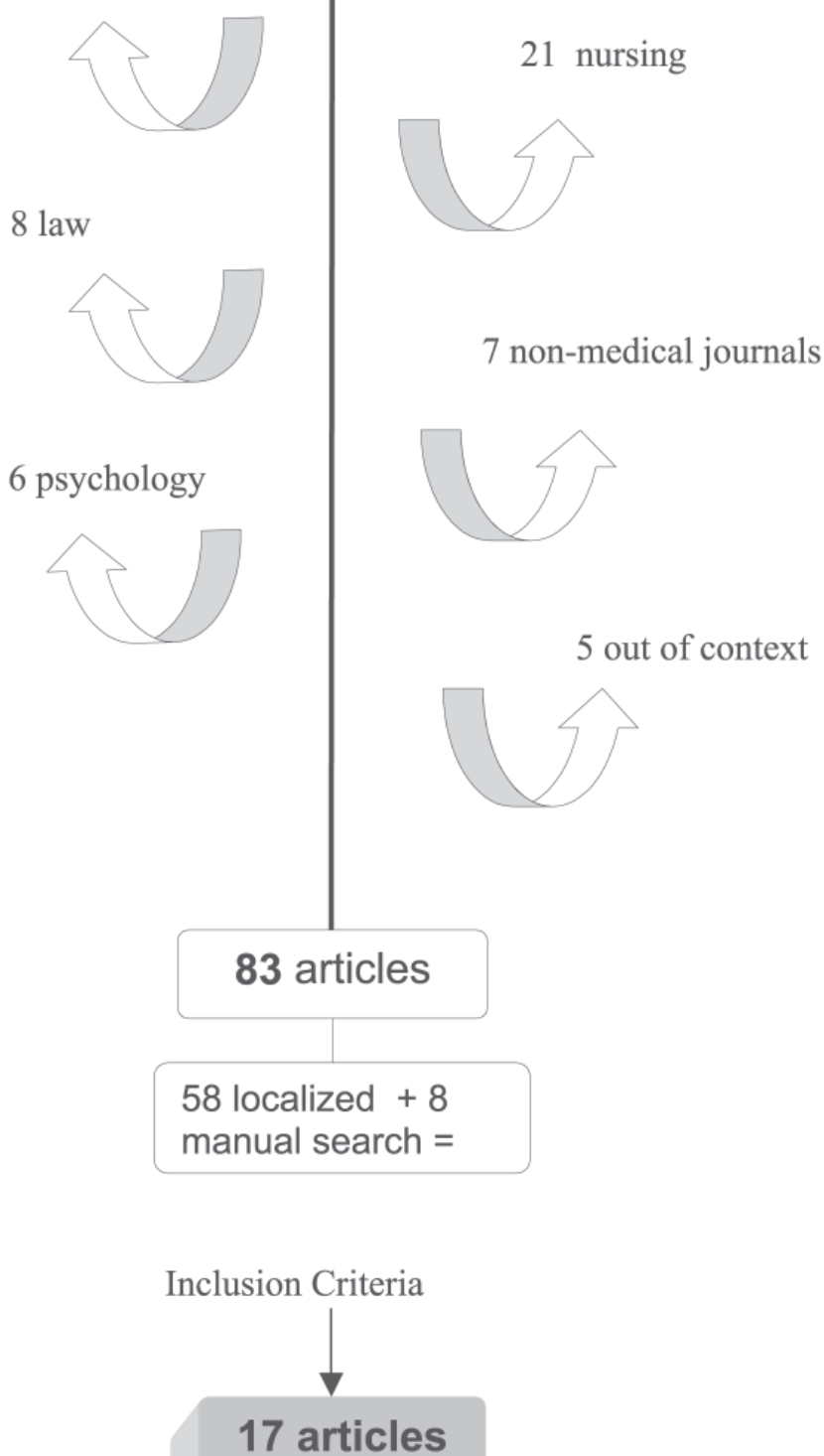

Figure 1 - Systematic review results after inclusion and exclusion criteria.

2.1 Justification and participation in the decision-making process

Four (4) cohort prevalence studies that quantified the justifications of the strategies adopted in the end-of-life care were found (Table 2). One study that was methodologically different was found and is described below.
Keenan 2000/USA ${ }^{21}$ : A prospective cohort study, multicentric (10 PICUs) that describes caregivers' attitudes toward limitation of medical support decisions for children and their justifications. These caregivers completed questionnaire for 262 of the 503 admitted patients. At least 1 justification was present for $63 / 503$ (12.5\%) of the patients. The ethical justifications for the staff response were:

a) "the suffering and the risks do not justify the potential benefit" (88\%);

b) "the treatment is unable to restore the previous quality of life" (83\%);

c) "inappropriate use of resources" (72\%);

d) "imminent death, independent from intensive treatment" (66\%).

For children who in fact underwent some intervention (that is mechanical ventilation, inotropics, parenteral nutrition), the intention of withdrawal of life support care in relation to the number of restricted therapies was statistically higher ${ }^{21}$. The decision-process was initiated by the PICU physician in $58 \%$ of cases, by the attending physician in $21 \%$, and by the nurse in $2 \%$. In $19 \%$ of cases, this information was not documented.

\section{Documentation in the chart of the processing strategy}

Only 2 studies that evaluated documentation in the charts were identified.

Melltrop et al./Sweden ${ }^{25}$ : Retrospective study that analyzed documentation in the chart of withholding (WH) or withdrawal (WD) of life support. 600 charts were reviewed; $34(6 \%)$ of these included a note of limited care at the end of life. In 20 (59\%) of these, there were decisions for $\mathrm{WH}$ and $\mathrm{WD}$; in 12 $(35 \%)$ there was a note about $\mathrm{WH}$; and in only $2(6 \%)$ of WD of life support. None of the charts included information regarding whether the procedure was discussed with the patient, but 18 
Table 1 - Summary of the studies referent to strategies adopted at the end of life in pediatric patients.

\begin{tabular}{|c|c|c|c|c|c|c|}
\hline Author/year (Country) & death / admission & WD $(\%)$ & WH $(\%)$ & DNR $(\%)$ & Euthanasia & Other $\mathrm{BD}+\mathrm{CPR}$ \\
\hline Mink/1992 (USA) $)^{14}$ & $50 / 795$ & & & $16(32) *$ & & $34(68.0)$ \\
\hline \multicolumn{7}{|l|}{ Vernon/1993 } \\
\hline$(\mathrm{USA})^{15}$ & $300 / 6000$ & $95(31.6)$ & & $78(26.0)$ & & 127 (42.3) USA \\
\hline Lantos/1993 (USA) $)^{16}$ & $54 / 795 \mathrm{~T}$ & & & $16(29.6)^{* *}$ & & $38(70.4)$ \\
\hline Levetown/1994 (USA) ${ }^{17}$ & $248 / 5415$ & $32(12.9)$ & $25(10.0)$ & $37(14.9)$ & & \\
\hline Balfour-Lynn/1996 (Londres) ${ }^{18}$ & $89 / 651$ & $45(50)$ & $13(15)$ & & & $31(35.0)$ \\
\hline Martinot/1998 (France $)^{19}$ & $92 / 712$ & $25(27.2)$ & & $25(27.2)$ & & $42(45.6)$ \\
\hline Goh/1999 (Malaysia) ${ }^{20}$ & $148 / 755$ & $7(4.7)$ & $68(45.9)$ & & & $73(49.3)$ \\
\hline Van der Wal/1999 (Holland) $)^{21}$ & $190 / 14903$ & $45(23.7)$ & $26(13.7)$ & $26(13.7)$ & $4(2.1)$ & $89(46.8)$ \\
\hline Carvalho/2001 (Brazil) $)^{22}$ & 44/ $419 \mathrm{Y}$ & $7(15.9)$ & $2(4.5)$ & $9(20.5)$ & & $26(59.0)$ \\
\hline TOTAL & $997 / 30444$ & $256(26)$ & $134(13)$ & $207(21)$ & $4(0.4)$ & $460(46.1)$ \\
\hline
\end{tabular}

DNR -Do-not-resuscitate order; WH / WD - Withhold / Withdraw life support care; BD-brain death; CPR- Cardiopulmonary resuscitation; * 12/16 (75\%) have done WD and/or WD; ** 7/16 (44\%) have done WD and/or WD; T 54 deaths were studied of 67 in total; Y 44 deaths were studied of 61 in total.

Table 2 - Justifications of restrictive therapies in terminally ill patients.

\begin{tabular}{|c|c|c|c|c|c|}
\hline $\begin{array}{l}\text { Justifications } \\
\text { Author/year }\end{array}$ & $\begin{array}{l}\text { Imminent death } \\
(\%)\end{array}$ & $\begin{array}{l}\text { No benefit of } \\
\text { therapy }(\%)\end{array}$ & $\begin{array}{l}\text { Unsatisfactory } \\
\text { therapy }(\%)\end{array}$ & $\begin{array}{l}\text { Severe neurologic } \\
\text { damage }(\%)\end{array}$ & $\begin{array}{l}\text { Lethal disease } \\
(\%)\end{array}$ \\
\hline Mink/1992 ${ }^{14}$ & & 69 & 31 & & \\
\hline Levetown/1994 ${ }^{17}$ & 70 & & 8 & 22 & \\
\hline Manara/1998 & 50 & & & 45 & 5 \\
\hline Van der Wal/1999²1 & 67 & & 33 & & \\
\hline
\end{tabular}

(53\%) documented that the family was aware and in 1 case that the family was involved in the decision. A majority of the decisions (nonquantified) were performed by the attending physician or the physician on call.

Torreão et al./Brazil ${ }^{26}$ : A 1-year retrospective cohort study in a tertiary hospital that evaluated the nonresuscitation of terminally ill patients. There were 47 deaths that followed nonresuscitation. Forty-five charts were reviewed, and in $5(11 \%)$ of them there was no note that reported death. From the 40 documented deaths, in $11(27 \%)$ the charts read "certificate of death", and in 29 (73\%) they read "resuscitative efforts were performed without success".

\section{DISCUSSION}

When compiling the results in table 1 , we were surprised to note that approximately $60 \%$ of the deaths that occurred in the PICUs followed care restrictions (WH/WD) of life support and nonresuscitative efforts. Similar reports are found in adult and neonatal ICU studies ${ }^{27-29}$.

The percentage of WD and WH of life support orders has been growingan average of 39\% - while the DNR order as isolated strategy was observed in only $21 \%$, accounting in all for $50 \%$ of the cases.

It is understandable that from the ethical point of view, the death of the terminally ill patient is a natural event that is sometimes even desirable, based in the bioethical principles of nonmalfeasance, beneficence, respect of autonomy, and justice ${ }^{3}$. However, while life support is artificially maintained, the non-use of resuscitative measures is not possible. In this terminal phase of the disease, the treatment is sometimes excessive, allowing the prolonging beyond "natural" of life, with consequences for the patient, the family, and society. With the DNR order, all the curative measures are maintained until death occurs. Therefore, when the expectations change from cure to caretaking, the WH and WD of life support have an important and coherent role in this new objective. It is understandable why the frequency of these strategies has increased in the ICUs in proportion with the increasing efficiency of new therapies in artificially supporting life that are not desirable for the patient in the terminal phase, since they will not improve the quality of life.

When euthanasia was considered, there was only 1 Dutch study that reported euthanasia in 4 patients whose suffering could not be sufficiently eliminated with the strategies of $\mathrm{WH}$ and/or WD of life support. This practice is legalized in Holland, but it is seen by the majority of countries as a homicide and is considered an illicit practice $^{30,31}$.

In this decision-making process, several ethical aspects can be referred to, but 2 of them are always contemplated: the best interest of the patient (related to the principle of beneficence and non-malfeasance) and the principle 
of autonomy or respect of the per$\operatorname{son}^{7,32,33}$.

The results of this study, according to Levetown, Manara, and Van Der Wal were that the medical justifications for the restrictive strategies were "imminent death" observed in 70\%, 50\%, and $67 \%$ of the studies respectively ${ }^{17,23,21}$, which shows the irreversibility of the process. In the study of Mink, in $6 \%$ of the cases the justification was "therapy with no benefit" 14 (Table 2). Both justifications were based in the saying "do good and do not cause harm", the Hippocratic rules that direct medical decisions.

Considering that the family or the legal guardians have the right to decide for their children and to act autonomously even though they are only representative, it is observed that in pediatrics, there is a tendency to valorize decisions based in the principles of beneficence and non-malfeasance. Therefore, the best interest of the child is primarily regarded, leaving the principle of autonomy as a secondary consideration, referring to benign paternalism to base the final decisions. The opposite occurs in the decisions relative to adult patients, where autonomy is primarily valued, and even for those who cannot make a conscious decision anymore, attempts are made to respect their "last wishes"16.

In Table 2, the justifications based on "unsatisfactory quality of life" and "severe neurological damage" (damage that does not allow for a relationship with the environment and therefore a worsening of quality of life follows) were observed in one-third of the cases. Keenan et al. ${ }^{24}$ showed that in $83 \%$ of cases, the decision was based in the affirmation that "treatment would not restore a previous quality of life".

Quality of life, as a justification for the strategies to limit life-support care for the terminally ill patient in the PICU, can be related to: a) the possibility of a future life with no relation- ship with the environment, i.e., with no potential for growth and development for a child regarding interactions with the environment and people; b) change in the previous condition, especially referring to severe neurological dysfunction, for example, the patient with hypoxic-ischemic encephalopathy following resuscitation. Even then, it is important to say that quality of life varies according to individual, sociocultural, and religious references.

In Keenan's study ${ }^{24}$, the justifications were obtained by questionnaires and were not mutually exclusive. Together with other justifications, in $72 \%$ of the cases the "inappropriate use of resources" was noted, which is based in the ethical principle of distributive justice and allocation of resources. The discussion is usually based in the defense of the best interest of the patient, but it is not anti-ethical to also consider the costs involved in the care of a terminally ill patient who uses the infrastructure of intensive care therapy, considering that there is a never-ending demand for ICU beds and that resources for health care are not unlimited even in developed countries ${ }^{34-36}$.

Concerning documentation in the charts, the ethically weighted attitude is that documentation of every step in the decision-making process of the end-of-life strategies for the terminally ill patient should occur ${ }^{3,32}$. The results of these studies ${ }^{25,26}$ prompt us to ask whether the absence of documentation of the decision-making process is a result of "forgetfulness" of physicians or is because it is "convenient not to register". Both hypotheses, unfortunately, are possible: the former, perhaps, because of lack of medical knowledge about the importance of the correct documentation in the chart; and the latter, probably, because of professional fear of being held judicially responsible. Several studies refer to the question of fear of legal implications $^{20,37,38}$.
The Brazilian study ${ }^{26}$ was an example of this attitude of physicians fearing the judicial process, revealing documentation of something that was not true in the chart when referring to the resuscitation process; a discrepancy from what was documented and what was done was observed. Despite the fact that resuscitative efforts were not performed, the chart read "resuscitative efforts performed without success" in $72 \%$ of the patients.

The authors discuss the equivocal interpretation of the article 57 from the Brazilian Medical Ethic Code that prohibits the physician "not to use all the available diagnostic and therapeutic resources in favor to the patient" ${ }^{26,39}$. Cardiopulmonary resuscitation should not be performed on the terminally ill patient, since it could not only prolong suffering but could also lead to a vegetative state of a biological life. The article 57, however, would not be applied in this phase of life.

In the Brazilian legal sense, it is important to consider the importance that physicians give to article 135 from the actual "Criminal Code" (1940) that refers to "omission of help", in the following terms: "not to provide assistance, when possible to do it without personal risk, to the abandoned or missing child, or to the disabled or hurt person, to the helpless, or in severe and imminent risk; or not to ask, in these cases, for appropriate authority help" ${ }^{40}$. The choice of not adopting resuscitative measures in the end of life could be wrongly interpreted as omission of help. However, since without the possibility of cure of the disease in its terminal phase it is evident that we cannot refer to the situation as "in severe and imminent risk", the article 135 from the Brazilian Legal Code is not applicable in these situations.

In the United States and in Europe, where restriction of therapy is practiced as a routine, studies show an incoherence between what profession- 
als believe, based on their clinical judgement, and in what they do in the clinical practice with regard to the terminally ill patient ${ }^{37,38}$.

Naturally, if the decision-making process had been done in a democratic way, as it would be expected, the documentation would reflect the trust established between the physician and the patient (and/or the family). In this context, there is no doubt that the physician is ethically supported in his professional attitudes, with decreased legal risks.

\section{CONCLUSIONS}

After this systematic review of the literature of the ethical aspects in the management of the terminally ill pa- tient in the PICU, we can conclude that:

Restrictive strategies (withdrawal or withhold life support or do-not-resuscitation orders) in pediatrics are involved in about $60 \%$ of the deaths in PICUs.

- The most commonly found medical justifications for restrictive strategies in the PICU were: "imminent death" and "poor quality of life" based on the bioethical principles of beneficence and non-malfeasance, contrary to what is found in the adult patient population, where the principle of autonomy is the primary consideration in the decision-making process.

- The principle of justice was rarely considered in the decisions of the terminally ill patient in the PICU.
- There was a gap in the documentation of the decision process, of the type of strategy adopted, and of the participation of the family.

- There is a incoherence between what the professionals believe in, based in their medical judgement, and in what they do in their routine practice.

\section{ACKNOWLEDGMENTS}

To the Bioethic Institutional Commission of the Children's Institute for their constructive comments in the development of this study.

And to my friend Liliana Simon for critically reviewing this manuscript and kindly translating it into English.

\section{RESUMO}

TORREÃO L de A e col. - Aspectos éticos na abordagem do paciente terminal em unidade de terapia intensiva pediátrica. Rev. Hosp. Clín. Fac. Med. S. Paulo 59(1): 39, 2004.

OBJETIVO: Identificar a prevalência das condutas e o processo de decisão na abordagem do paciente terminal na UTI pediátrica.

METODOLOGIA: Revisão sistemática da literatura. seguindo os critérios da medicina baseada em evidên- cias. nas seguintes bases de dados: LILACS (1982-2000) e MEDLINE (1966-2000). usando os descritores abaixos limitados para a idade (0 a 18 anos).

RESULTADOS: Foram selecionados 183 artigos e após análise dos critérios de exclusão / inclusão e os objetivos restaram 17 artigos. As condutas mais prevalentes foram: ordem de não ressuscitar. omissão e/ou suspensão de suporte de vida. As justificativas mais encontradas para tais condutas foram: "morte iminente" e "quali- dade de vida insatisfatória".

CONCLUSÃO: A abordagem tem base nos princípios éticos e visa maximizar o benefício e evitar a distanásia. se possível. respeitando a autonomia do paciente terminal.

DESCRITORES: Doente terminal. Pediatria. Condutas restritivas. Ética médica. Unidade de terapia intensiva pediátrica.

See editorial in this issue.

\section{REFERENCES}

1. Prendergast TJ. Resolving conflicts surrounding end-of-life care. N. Horiz., 1997,v.5, p.62-71.

2. Todres ID. Dilemas éticos no tratamento intensivo pediátrico. Crit. Care Clin., 1992, v.8, p.247-55.

3. Piva JP, Carvalho PA. Considerações éticas nos cuidados médicos do paciente terminal. Bioética, 1993, v.1, p.129-38.
4. Fletcher JC, Eys JV, Dorn LD. Ethical considerations in pediatric oncology. In: Pizzo PA, Poplack DG. Principles and practice of pediatric oncology. 3. ed. Philadelphia, Lippincott-Raven, 1997. p.1283-300.

5. Holbrook P, Glover J. Ethical considerations. In: Holbrook WB. Textbook of pediatric critical care. 3. ed. Philadelphia, Saunders, 1993. p.1124-30. 
6. Pessini L, Barchifontaine CP. Bioética: do principialismo à busca de uma perspectiva Latino-Americana. In: Costa SF, Oselka G, Garrafa V. coord. Iniciação à bioética. Brasília, Conselho Federal de Medicina, 1998. p.81-98.

7. Beauchamp TL, Childress JF. Principles of biomedical ethics. 4. ed. New York, Oxford University Press, 1994.

8. Martin LM. Eutanásia e distanásia. In: COSTA SF, OSELKA G, GARRAFA,, V. coord. Iniciação à bioética. Brasília, Conselho Federal de Medicina, 1998. p.171-92.

9. Pessini L - Distanásia: até quando investir sem agredir? Bioética, (Online). Disponível: http:// www.cfm.org.br/ revista/bio1v7/ distanasia.html

10. Clotet J, Frnciscone CF, Goldim JR - Consentimento informado e a sua prática na assistência e pesquisa no Brasil. Porto Alegre, EDIPUCRS, 2000.

11. American Academy of Pediatrics. Policy Statement. Informed consent, parental permission, and assent in pediatric practice. Pediatrics, 1995, v.95, p.314-7.

12. Pessini L, Barchifontaine CP. Problemas atuais de bioética. 4. ed. São Paulo, Edições Loyolas, 1997. p.43-58: Princípios e conceitos fundamentais de bioética.

13. Cook DJ, Sackett DL, Spitzer WO. Methodologic guidelines for systematic reviews of randomized control trials in health care from the postdam consultation on meta-analysis. J. Clin. Epidemiol., 1995, v.48, p.167-71.

14. Mink BR, Pollack MM. Resuscitation and withdrawal of therapy in pediatric intensive care. Pediatrics, 1992, v.89, p.961-3.

15. Vernon DD, Dean JM, Timmons OD, Banner W, Allen-Webb EM. Modes of death in the pediatric intensive care unit: withdrawal and limitation of supportive care. Crit. Care Med., 1993, v.21, p.1798-802.

16. Lantos JD, Berger AC, Zucker AR. Do-not-resuscitate orders in a children's hospital. Crit. Care Med., 1993, v.21, p.52-5.

17. Levetown M, Pollack MM, Cuerdon TT, Ruttiman UE, Glover JJ. Limitations and withdrawals of medical intervention in pediatric critical care. JAMA, 1994, v. 272, p. 1271-5.

18. Lynn IB, Tasker RC. At the coalface - medical ethics in practice. Futility and death in paediatric medical intensive care J. Med. Ethics, 1996, v.22, p.279-81.

19. Martinot A, Grandbastien B, Leteurtre S, Duhamel A. No resuscitation orders and withdrawal of therapy in French paediatric intensive care units. Acta Paediatr., 1998, v.87, p.76973.

20. Goh AT, Lum LS, Chan PK, Chong BO. Withdrawal and limitation of life support in paediatric intensive care. Arch. Dis. Child., 1999, v.80, p.424-8.

21. Van Der Wal ME, Renfurm LN, Van Vught AJ, Gemke RJ. Circumstances of dying in hospitalized children. Eur. J. Pediatr., 1999 , v. 158 , p.560-5.

22. Carvalho PA, Rocha TS, Espírito Santo A, Lago P. Modos de morrer na UTI pediátrica de um hospital terciário. Rev. Assoc. Med. Bras. 2001, v.47 n.4.
23. Manara AR, Pittman JL, Braddon FM. Reasons for withdrawing treatment in patients receiving intensive care. Anaesthesia, 1998 , v. 53 , p. $523-8$

24. Keenan HT, Diekema DS, O'Rourke PP, Cummings P, Woodrum DE. Attitudes toward limitation of support in a pediatric intensive care unit. Crit. Care Med. 2000, v.28, p.1590-4.

25. Melltrop G, Nilstun T - Decisions to forego life-sustaining treatment and the duty of documentation. Intensive Care Med. 1996, v.22, p. $1015-9$.

26. Torreão LA, Reis AC, Troster EJ, Oselka G. Ressuscitação Cardiopulmonar: discrepância entre o procedimento de ressuscitação e o registro no prontuário. J. Pediatr., 2000, v.76, p.429-33.

27. Keenan SP, Busche KD, Chen LM, EsmaiL R, Inman KJ, Sibbald WJ. Withdrawal and withholding of life support in the intensive care unit: a comparison of teaching and community hospitals. Crit. Care Med., 1998, v. 26, p.245-51

28. Jayers RL, Zimmerman JE, Wagner DP, Draper EA, Knaus WA. Do-not-resuscitate orders in intensive care units: current practices and recent changes. JAMA, 1993, v.270, p.2213-7

29. RYAN AC, BYRNE P, KUHN S, TYEBKHAN J - No resuscitation and withdrawal of therapy in neonatal and a pediatric intensive care unit in Canada. J. Pediatr., 1993, v.123, p.534-8.

30. Eutanásia Holanda. Goldim. (Online). Disponível: http:// www.ufrgs.br/HCPA/gppg/eutanhol.htm (16/04/01).

31. Euthanasia in Holland. (Online). Disponível: http:// www.euthanasia.org/dutch.html (16/04/01)

32. Americam Academy Of Pediatrics - Guidelines on forgoing lifesustaining medical treatment. Pediatrics, 1994, v.93, p.532-6.

33. British Medical Association - Withholding or withdrawing lifeprolonging medical treatment. Guidance for decision making. Londres, BMJ Publishing Group, 1999. p.25-45.

34. Sachdeva RC, Jefferson LS, Coss-Bu J, Brody BA - Resources consumption and the extent of futile care among patients in a pediatric intensive care unit setting. J. Pediatr., 1996, v.128, p.742-7.

35. Lanken PN, Terry PB, Osborne ML. Ethics of allocating intensive care unit resources. N. Horiz., 1997, v.5, p.38-50.

36. Neves MP. Alocação de recurso em saúde: considerações éticas. Bioética, 1999, v.7, p.155-63.

37. The Support principal investigators. A controlled trial to improve care for seriously ill hospitalized patients: Study to Understand Prognoses and Preferences for Outcomes and Risks of Treatment (SUPPORT). JAMA, 1995, v.274, p.1591-8.

38. Vincent JL. Forgoing life support in western European intensive care units: the results of an ethical questionnaire. Crit. Care Med., 1999, v.27, p.1626-33.

39. Conselho Federal de Medicina - Código de Ética Médica. Resolução $\mathrm{n}^{0} 1246 / 88$, de 08 de janeiro de 1988. Aprova o novo Código de Ética de Médica. Diário Oficial da União, 26 jan. 1988.

40. Brasil - Decreto-lei n. 2.848 de 7 dez. 1940. Código Penal Brasileiro. 